\title{
PERILAKU PEKERJA SEKS KOMERSIAL TERHADAP PENCEGAHAN PENYAKIT MENULAR SEKSUAL DI LOKALISASI KALINYAMAT BANDUNGAN
}

\author{
Triwik Sri Mulati, Indarto, Putri Ratnasari \\ Kementrian Kesehatan Politehnik Kesehatan Surakarta Jurusan Kebidanan
}

\begin{abstract}
Behavior, Commercial sex workers, Sexually transmitted diseases. This study aims to reveal the phenomenon of Conduct Against Commercial Sex Workers Sexually Transmitted Disease Prevention at Localization Kalinyamat, Bandungan. This study used a qualitative design with sample collection technique is purposive sampling with maximum sampling type of sampling variation. The collection of data by using a technique Focus Group Discussion (FGD) and In-depth Interviews (WM). In this study, researchers used informants DKT 6 and 8 informants WM. Test the validity of the data was done by using triangulation. The results showed that the behavior of prostitutes on the prevention of STDs seen from most of the knowledge already know about the definition, causes, types, signs and symptoms of STD prevention, of attitudes that are divided into several categories there who agree and disagree, on the activities on the prevention largely meet health standards.
\end{abstract}

Keywords: Behavior, Commercial Sex Workers, Sexually Transmitted Diseases

\begin{abstract}
Abstrak: Perilaku, Pekerja Seks Komersial, Penyakit Menular Seksual. Penelitian ini bertujuan untuk mengungkap fenomena Perilaku Pekerja Seks Komersial Terhadap Pencegahan Penyakit Menular Seksual di Lokalisasi Kalinyamat, Bandungan. Penelitian ini menggunakan rancangan kualitatif dengan teknik pengumpulan sampel secara purposive sampling dengan jenis sampling maximum variation sampling. Adapun pengumpulan data dengan menggunakan teknik Diskusi Kelompok Terarah (DKT) dan Wawancara Mendalam (WM). Dalam penelitian ini peneliti menggunakan 6 informan DKT dan 8 informan WM. Uji keabsahan data dilakukan dengan teknik triangulasi. Hasil penelitian menunjukkan bahwa perilaku PSK terhadap pencegahan PMS dilihat dari pengetahuan sebagian besar sudah mengetahui tentang pengertian, penyebab, jenis, tanda gejala dan pencegahan PMS, dari sikap yang dibagi menjadi beberapa kategori ada yang setuju dan tidak setuju, dari aktifitas terhadap pencegahan sebagian besar sudah memenuhi standar kesehatan.
\end{abstract}

Kata Kunci: Perilaku, Pekerja Seks Komersial, Penyakit Menular Seksual

\section{PENDAHULUAN}

Penyakit Menular Seksual (PMS) didefinisikan sebagai salah satu akibat yang ditimbulkan karena aktifitas seksual yang tidak sehat sehingga menyebabkan munculnya penyakit menular seksual, bahkan pada beberapa kasus PMS yang membahayakan, misalnya HIV (Human Immunodeficiency Virus), sifilis, gonore, dll. (Intan, 2012 dan iwan, 2012).
Penyakit menular seksual adalah istilah umum dan organisme yang menjadi penyebabnya biasanya masuk dalam darah atau cairan tubuh, yaitu meliputi virus, mikoplasma, bakteri, jamur,dan parasit-parasit kecil, yang cara penularannya dengan kontak tubuh termasuk berciuman, hubungan seksual, hubungan seksual melalui anus, juga kontak mulut atau genital dengan payudara. (Ralph, 2009). Angka 
kejadian Penyakit Menular Seksual (PMS) saat ini cenderung meningkat di Indonesia. Jumlah kasus infeksi menular seksual di Provinsi Jawa Tengah dari tahun ke tahun semakin meningkat. Peningkatan kasus ini dikarenakan pencatatan dan pelaporan yang semakin baik. Meskipun demikian kemungkinan kasus yang sebenarnya di populasi masih banyak yang belum terdeteksi. Di Provinsi Jawa Tengah pada tahun 2009, kasus PMS diobati sebesar 77,80\%, mengalami penurunan bila dibandingkan dengan cakupan tahun 2008 sebesar $98,14 \%$. Ini berarti belum seluruh kasus PMS yang ditemukan diobati atau belum mencapai target yaitu 100\%. (Dinkes, 2009). Berdasarkan data dari Dinas Kesehatan Kota Semarang tahun 2009, ada beberapa PMS yang mengalami penurunan dibandingkan tahun 2008 diantaranya kandidiasis dari 443 menjadi 308, bakteri vagina dari 151 menjadi 144, HIV dari 114 menjadi 9, gonorrhoe dari 120 menjadi 71, condyloma acuminate dari 95 menjadi 68, herpes genetalis dari 68 menjadi 59, AIDS dari 23 menjadi 17 dan syphilis dari 6 menjadi 2. Demikian pula beberapa kasus yang meningkat antara lain herpes simplex dari 140 menjadi 149 dan trichomonas vaginalis dari 6 menjadi 9 . Meskipun begitu belum semua unit pelayanan baik rumah sakit maupun Puskesmas melaporkan data PMS ke Dinas Kesehatan Kota Semarang. Menurut Organisasi Kesehatan Wanita (WHO) ada beberapa faktor yang menyebabkan angka kejadian PMS antara lain, Mulai aktif secara seksual pada usia dini, sering berganti - ganti pasangan, perokok berat, mengkonsumsi alkohol, melakukan hubungan seks tanpa pelindung, dan pekerja seks komersial. Menurut Verra, (2011) wanita lebih beresiko untuk terkena PMS lebih besar dari pada laki-laki sebab mempunyai alat reproduksi yang lebih rentan.

Pekerja Seks Komersial (PSK) adalah suatu pekejaan atau profesi dengan melacurkan diri, penjualan diri dengan jalan memperjualbelikan badan, kehormatan dan kepribadian kepada banyak orang untuk memuaskan nafsunafsu seks dengan imbalan pembayaran, dengan alasan komersial mereka siap melakukan apa saja untuk kepuasan pelanggan sampai pada perilaku seks yang tidak sehat, sehingga kelompok ini beresiko untuk terkena penyakit menular seksual (PMS). Pekerja seks komersial sangat rentan terinfeksi Penyakit Menular Seksual karena pekerjaan nya yang berganti-ganti pasangan melakukan hubungan seksual. Pekerjaan PSK yang melakukan hubungan seksual dengan banyak pasangan tentunya mengkhawatirkan kita, karena penyakit menular seksual yang mungkin menginfeksi PSK dapat menginfeksi istri dari laki-laki pengguna PSK tersebut. Dari data yang dihimpun Puskesmas Bandungan bahwa di lokalisasi kalinyamat terdapat 228 pekerja seks komersial, yang berdasarkan hasil pemeriksaan setiap bulannya data Pekerja Seks Komersial yang terkena 4 Penyakit Menular dari bulan januari sampai desember sebanyak 80 pekerja seks yang menderita penyakit menular, dan kebanyakan dari mereka menderita vaginasitis, yang menderita gonore sebanyak 10 orang, Ca serviks 4 orang, HIV/AIDS 1 orang, dan berdasarkan tempat tinggal nya dibagi 2 yaitu ada yang tinggal di kos dan panti,di lokasi tersebut terdapat 18 kos dan 13 panti. Berdasarkan study pendahuluan hasil wawancara pada 5 informan, di dapatkan hasil bahwa 3 diantaranya pernah menderita penyakit menular seksual dan 2 informan mengatakan tidak pernah menderita penyakit menular seksual, Dari 3 informan yang pernah menderita penyakit menular seksual di dapatkan bahwa dari aktifitas merekalah yang menyebabkan PMS tersebut diantaranya yaitu aktifitas seksual yang sering melakukan hubungan seksual lebih dari 
3 kali sehari dengan pasangan yang berbeda, saat melakukan hubungan seksual tidak menggunakan kondom, walaupun sudah ada penyuluhan dan pemeriksaan PMS seminggu 2 kali, namun mereka beranggapan bahwa pemeriksaan itu bukan salah satu dari kebutuhan mereka,melainkan kebutuhan petugas kesehatan,dari 2 informan yang tidak pernah mengalami penyakit menular seksual didapatkan hasil bahwa mereka melakukan aktifitas seksual nya biasa-biasa saja,masih dalam batas normal, sering menggunakan kondom, mungkin ini dipengaruhi juga karena mereka masih terbilang baru di dunia ini. Maka hal ini menarik peneliti untuk mengetahui Perilaku Pekerja Seks Komersial terhadap Penyakit Menular Seksual di Lokalisasi Kalinyamat Bandungan, yaitu salah satu lokalisasi terbesar di kab. Semarang. salah satu lokalisasi terbesar di kab. Semarang.

\section{METODE PENELITIAN}

Penelitian ini adalah penelitian fenomenologi yang akan mengungkap fenomena-fenomena tentang Perilaku pekerja Seks Komersial di Lokalisasi Kalinyamat, Bandungan dengan metode pengambilan data secara kualitatif, yaitu suatu penelitian yang bermaksud untuk memahami fenomena tentang apa yang dialami oleh subjek penelitian, dengan cara mendreskripsikan dalam bentuk kata-kata dan bahasa pada suatun konteks khusus yang alamiah dan dengan memanfaatkan berbagai metode alamiah (Moleong, 2010).

Penelitian ini dilakukan di lokasi Puskesmas pembantu Bandungan, Gang ngunut, Gang Kalinyamat Bandungan dilaksanakan mulai bulan Oktober 2012. Pengambilan subyek penelitian menggunakan metode purposive sample dengan jenis sampling adalah maximum variation sampling yaitu memilih variasi fenomena yang beragam dengan tujuan memperoleh variasi yang maksimal, beragam, unik, serta mengidentifikasi pola-pola yang sering dijumpai (Moleong, 2010). Jumlah sampel pada penelitian ini sejumlah 14 informan.

\section{HASIL PENELITIAN}

Bandungan sebenarnya merupakan tempat wisata, akan tetapi lebih dikenal sebagai tempat prostitusi. Setiap menyebut nama Bandungan, imajinasi orang selalu kepada perempuan. Lokasi Bandungan berada di sebelah selatan kurang lebih $45 \mathrm{Km}$ dari Kota Semarang, Ibu Kota Propinsi Jawa Tengah, dan tempat penelitian yang peneliti gunakan tepatnya di puskesmas pembantu bandungan, gang kalinyamat, dan gang ngunut, Letak Bandungan di sebelah utara berbatasan dengan Desa Sidomukti, Sebelah Selatan berbatasan dengan dengan Desa Paseban, Sebelah Barat berbatasan dengan Desa Kenteng dan Sebelah Timur berbatasan dengan Desa Jetis. Di lokasi bandungan terdapat 18 kos dan 13 panti. Informan dalam penelitian ini berjumlah 14 informan yang berasal dari kos dan panti yang berbeda. Dalam proses pengumpulan data peneliti menggunakan teknik Diskusi Kelompok Terarah (DKT) yang dilakukan satu kali dengan jumlah informan 6 informan dan wawancara mendalam yang dilakukan sebanyak 4 kali dengan jumlah informan 8 informan dan dilakukan dalam waktu yang berbeda. 50 2. Perilaku Pekerja Seks Komersial terhadap pencegahan penyakit menular seksual di lokasi bandungan.

Penelitian tentang pekerja seks komersial terhadap pencegahan penyakit menular seksual ini meliputi 3 sub fenomena yaitu pengetahuan pekerja seks komersial terhadap pencegahan penyakit menular seksual, sikap pekerja seks komersial terhadap penyakit menular seksual, dan aktifitas pekerja seks komersial terhadap pencegahan penyakit menular seksual. 
Adapun hasil dari masing-masing sub fenomena itu dapat di uraikan sebagai berikut :

a. Pengetahuan Pekerja Seks Komersial terhadap pencegahan menular seksual di lokasi kalinyamat bandungan. Untuk mengetahui pengetahuan pekerja seks komersial terhadap pencegahan penyakit menular seksual terdapat beberapa sub fenomena meliputi :

1. Pengetahuan pekerja seks komersial terhadap penyakit menular seksual tentang Pengertian penyakit menular seksual. Menurut pengetahuan informan penelitian mengenai pengertian tentang penyakit menular seksual yaitu suatu penyakit yang ditularkan karena hubungan seksual dan sering bergonta-ganti pasangan. Untuk factor penyebabnya ada beberapa macam yaitu secara langsung: hubungan seksual; virus dan bakteri; secara tidak langsung: Kebersihan diri kurang, Ciuman, Kontak badan yang dekat, makanan.

2. Pengetahuan pekerja seks komersial tentang jenis penyakit menular seksual dan tanda gejala penyakit menular seksual. Pengetahuan pekerja seks komersial tentang jenis penyakit menular seksual masih terbatas hanya beberapa yang sering mereka jumpai yang disebutkan misalnya sipilis, jengger ayam, HIV/AIDS. Dan untuk tanda gejala penyakit tersebut sudah banyak yang mengerti dan tahu tentang tanda dan gejala timbulnya penyakit menular seksual:

Tabel 1

Pengetahuan PSK terhadap PMS tentang jenis, tanda gejala penyakit menular seksual

\begin{tabular}{|c|c|c|c|}
\hline No & Jenis PMS & Penyebab & Tanda gejala \\
\hline 1 & HIV/Aids & Virus & $\begin{array}{l}\text { Berat badan } \\
\text { turun, diare, } \\
\text { flu, keringat } \\
\text { di malam } \\
\text { hari }\end{array}$ \\
\hline 2 & Herpes & Virus & $\begin{array}{l}\text { Gatal, } \\
\text { demam, bau }\end{array}$ \\
\hline 3 & $\begin{array}{l}\text { Jengger } \\
\text { ayam }\end{array}$ & Virus & $\begin{array}{l}\text { Ada } \\
\text { benjolan } \\
\text { bergerumbul } \\
\text { seperti } \\
\text { jengger, }\end{array}$ \\
\hline 4 & Sipilis & Bakteri & $\begin{array}{l}\text { Demam, ada } \\
\text { luka di } \\
\text { vagina }\end{array}$ \\
\hline 5 & $\begin{array}{l}\text { Gonore/ } \\
\text { Kencing } \\
\text { nanah }\end{array}$ & Bakteri & $\begin{array}{l}\text { Nyeri saat } \\
\text { kencing, } \\
\text { keluar nanah } \\
\text { dari alat } \\
\text { kelamin, } \\
\text { demam }\end{array}$ \\
\hline
\end{tabular}

komersial tentang pencegahan terhadap penyakit menular seksual dan penanganannya dalam penelitian ini diperoleh hasil jawaban yang bervariasi. Adapun jawaban tersebut dikelompokkan ke dalam tiga kategori yaitu pencegahan penyakit menular seksual, penanganan, dan tempat mendapat informasi tentang penyakit menular seksual.

Sikap pekerja seks komersial tentang memilih-milih tamu Informan berpendapat berbeda dalam memilihmilih tamu ada yang setuju dan ada yang tidak setuju. Pada pernyataan ini informan menyebutkan alasan yang berbeda-beda untuk melandasi pendapat tersebut. Alasan mengenai sikap pekerja seks komersial tentang memilih-milih tamu dapat dilihat secara rinci pada tabel sebagai berikut :

\section{Tabel 2}

Sikap pekerja seks komersial tentang tentang memilih-milih tamu

\begin{tabular}{ll}
\hline Setuju & Tidak Setuju \\
Alasan : & Alasan : \\
1. Takut & 1. Banyak uang \\
a. Tertular & 2. Yang penting \\
penyakit & Baik hati dan sopan \\
b. Dirampok & 3. Yang penting dibayar \\
\hline
\end{tabular}




\section{PEMBAHASAN}

Berdasarkan hasil penelitian mengenai perilaku pekerja seks komersial terhadap pencegahan penyakit menular seksual diketahui bahwa terdapat tiga sub fenomena yaitu pengetahuan, sikap dan aktivitas pekerja seks komersial terhadap pencegahan penyakit menular seksual. Berikut ini peneliti uraikan hasil dari penelitian dari masing-masing sub fenomena beserta pembahasan data hasil.

Pengetahuan adalah hasil dari tahu yang terjadi setelah seseorang melakukan pengindraan pada obyek tertentu melalui penglihatan dan pendengaran. Dalam penelitian ini terdapat tiga sub fenomena dari pengetahuan yang digunakan untuk mengungkap pengetahuan perilaku pekerja seks komersial terhadap pencegahan penyakit menular seksual.

Pengetahuan pekerja seks komersial terhadap pencegahan penyakit menular seksual tentang pengertian dan faktor penyebab. Berdasarkan hasil penelitian mengenai pengetahuan pekerja seks komersial tentang pengertian dan factor penyebab penyakit menular seksual maka didapatkan hasil bahwa pengertian penyakit menular ini adalah penyakit karena hubungan seksual yang disebabkan oleh virus dan juga karena sering bergonta ganti pasangan Pendapat ini senada dengan (Verra, 2012) yaitu Penyakit menular seksual (PMS) adalah penyakit yang ditularkan melalui hubungan seks, penyakit menular seksual akan lebih beresiko bila melakukan hubungan seksual dengan berganti-ganti pasangan baik melalui vagina, oral maupun anal. Menurut Manuaba, (2009) Penyakit Menular Seksual adalah penyakit yang cara penularannya melalui hubungan kelamin, tempat terjangkitnya penyakit tersebut tidak semata-mata pada alat kelamin saja, tetapi dapat terjadi di berbagai tempat di luar alat kelamin. Kemudian untuk factor penyebab terjadinya penyakit menular seksual di dapatkan hasil disebabkan karena bergonta-ganti pasangan, gantian jarum suntik, berhubungan dengan penderita, tidak memakai kondom, seks usia dini, kurang nya pengetahuan profesi PSK, melakukan seks tidak sehat yaitu anal seks, dan pendapat ini hampir senanda dengan intan (2012) ada beberapa penyebab terjadinya Penyakit Menular Seksual: 1) Sisa kotoran yang tertinggal karena pembasuhan buang air besar yang kurang sempurna, 2) Kesehatan umum rendah, 3) Kurangnya kebersihan alat kelamin, terutama saat menstruasi, 4) Perkawinan pada usia terlalu muda dan berganti-ganti pasangan, 5) Hubungan seksual dengan penderita infeksi, 6) Perlukaan pada saat keguguran, melahirkan, atau perkosaan, 7) Kegagalan pelayanan kesehatan dalam strelisisasi alat dan bahan dalam melakukan pemeriksaan/ tindakan di sekitar saluran reproduksi.Selain itu intan (2012) juga berpendapat bahwa orang-orang yang beresiko tinggi terhadap penularan PMS, termasuk HIV/AIDS yaitu: 1) Sering bergantiganti pasangan atau mempunyai satu atau lebih pasangan seksual baik yang dikenal maupun yang tidak dikenal (misalnya dengan pekerja seks komersial), 2) Memiliki pasangan seksual yag mempunyai pasangan seksual lainnya, 3) Terus melakukan hubungan seksual, walaupun mempunyai keluhan PMS dan tidak memberitahu kepada pasangannya tentang hal tersebut, 4) Tidak memakai kondom saat melakukan hubungan seksual dengan pasangan yang beresiko, 5) Pemakaian jarum sutik secara bersama-sama secara bergantian, misalnya pada penderita ketergantungan naerkotika atau kelalaian petugas dalam menjaga kesterilan alat suntik, 6) Pekerja seks komersial, 7) Homoseksual

Berdasarkan hasil penelitian mengenai pengetahuan pekerja seks komersial tentang jenis dan tanda gejala 
penyakit menular seksual maka didapatkan hasil jenis penyakit menular seksual dapat di kategorikan menurut cara penularan nya melalui virus dan bakteri adapun jenisnya yaitu HIV, Sipilis, Herpes, Kencing nanah, Jengger ayam dan untuk tanda gejala informan menyebutkan beberapa pendapat di antaranya nyeri saat kencing, terdapat benjolan/bintil-bintil, pipis nanah, gatal, keputuhan berbau dan berwarna Pendapat ini senada dengan verra dan taufan, (2011) .

Sikap pekerja seks komersial tentang profesi nya yang beresiko terhadap penyakit menular seksual. Menanggapi pernyataan sikap ini informan menyatakan setuju dengan profesinya sebagai pekerja seks komersial itu beresiko terhadap penyakit menular seksual dengan alasan karena terlanjur mengandalkan profesi, butuh uang, sulitnya mendapat pekerjaan karena factor ijasah, hal ini tidak sependapat dengan suryati dan anna (2009) karena ada beberapa masalah dan dampak yang dihadapi pada wanita yaitu ancaman kesehatan tinggi antara lain: a) Resiko tinggi tertular dan menularkan penyakit menular seksual (PMS) terutama penyakit kelamin seperti gonorrhea, sifilis, herpes genital, condiloma akuminata dan ulcus mole. Penyakit tersebut menimbulkan cacat jasmani dan rohani pada diri sendiri dan anak keturunan. Selain itu dapat pula tertular penyakit infeksi menular seksual seperti kandidiasis, vaginosis bacterial dah HIV/AIDS. b) Resiko terjadinya kehamilan yang tidak diinginkan. Wanita tuna susila yang melakukan hubungan seks tanpa pengaman akan menyebabkan terjadinya kehamilan. Karena kehamilan yang tidak diinginkan, maka wanita akan melakukan aborsi yang tidak aman yang dapat mengancam jiwa. c) Gangguan pada kesehatan reproduksi.

Karena seringnya berganti-ganti pasangan maka akan mengganggu kesehatan reproduksi wanita tersebut dimana wanita akan terkena infeksi pada alat reproduksinya yang dapat menyebabkan kemandulan dan kanker serviks. Hal ini menunjukkan tingkatan sikap dari informan yaitu bertanggung jawab, sesuai dengan Notoatmodjo (2010) bahwa bertanggung jawab (responsible) merupakan tingkatan sikap yang paling tinggi tingkatnya. Seseorang yang telah mengambil mengambil sikap tertentu berdasar keyakinannya, dia harus berani mengambil risiko bila ada orang lain yang mencemooh, atau ada resiko lain.

Menanggapi pernyataan sikap ini informan menyatakan ada yang setuju dan tidak setuju, yang setuju dengan alasan takut tertular penyakit kalau tidak hati-hati ini sesuai dengan teori intan (2012) Angka kesakitan kelompok umur tertentu pada penderita penyakit menular seksual pria adalah lebih tinggi dibandingkan dengan wanita. dan ada juga yang beranggapan tidak setuju dengan alasan untuk mendapat banyak uang, yang penting baik hati, yang penting dibayar hal ini menunjukkan bahwa tingkatan sikap dari informan adalah Menerima (receiving) sesuai dengan notoadmojo (2010) bahwa Menerima diartikan bahwa orang (subyek) mau dan memperhatikan stimulus yang diberikan (obyek).

Sikap pekerja seks komersial tentang melakukan pemeriksaan rutin terhadap penyakit menular seksual. Menanggapi pernyataan sikap ini informan menyatakan ada yang setuju dan tidak setuju, yang setuju dengan alasan mencegah penyakit, cek kesehatan, menambah pengetahuan pendapat ini sesuai dengan teori saroha (2009) Segera memeriksakan diri serta melakukan konseling ke dokter atau petugas kesehatan apabila mengalami tanda dan gejala penyakit menular seksual, meliputi rasa sakit atau nyeri pada saat kencing atau berhubungan seksual, rasa nyeri pada perut bagian 
bawah, pengeluaran lendir pada vagina/ alat kelamin, keputihan berwarna putih susu, bergumpal dan disertai rasa gatal dan kemerahan pada alat kelamin atau sekitarnya, keputihan yang berbusa, kehijauan, berbau busuk, dan gatal, timbul bercak-bercak darah setelah berhubungan seks, bintil-bintil berisi cairan, lecet atau borok pada alat kelamin). Sebagian informan yang lain tidak setuju dengan pemeriksaan rutin yang di sebutkan dalam berbagai alasan yaitu mengganggu istirahat, tidak ada waktu luang periksa jika merasa merasa sakit. Hal ini menunjukkan bahwa tingkatan sikap informan adalah Menerima (receiving) sesuai dengan notoadmojo (2010) bahwa Menerima diartikan bahwa orang (subyek) mau dan memperhatikan stimulus yang diberikan (obyek).

Sikap pekerja seks komersial terhadap kesehatan diri. Menanggapi pernyataan sikap ini informan menyatakan tidak setuju, ini sesuai dengan teori eko bastyansyah (2008) Kesehatan adalah keadaan sejahtera dari badan, jiwa, dan sosial yang memungkinkan setiap orang hidup produktif secara sosial dan ekonomis. Pemeliharaan kesehatan adalah upaya penaggulangan dan pencegahan gangguan kesehatan yang memerlukan pemeriksaan, pengobatan dan/atau perawatan termasuk kehamilan dan persalinan.

\section{KESIMPULAN DAN SARAN}

Dalam penelitian mengenai perilaku pekerja seks komersial terhadap pencegahan penyakit menular seksual di lokasi kalinyamat bandungan, dapat disimpulkan. Pengetahuan Pekerja Seks Komersial terhadap pencegahan menular seksual di lokasi kalinyamat bandungan. Mengenai pengertian dan factor penyebab sebagian informan sudah mengetahui pengertian juga dapat menyebutkan penyebab terjadinya penyakit menular seksual. Pemahaman informan sudah sampai pada tingkatan memahami yang di tunjukkan dengan pendapat informan yang mampu menjelaskan tentang pengertian penyakit menular seksual dan menyebutkan factor penyebab penyakit menular seksual dengan benar. Pemahaman informan tentang jenis dan tanda gejala penyakit menular masih sekedar tahu tetapi beberapa informan ada yang sudah memahami tentang jenis dan tanda gejala penyakit menular seksual. Selanjutnya pemahaman informan mengenai pencegahan terhadap penyakit menular seksual sudah pada tahap memahami karena mereka sudah sadar dengan sendirinya periksa jika mengalami tanda-tanda penyakit menular seksual dan tau cara mencegah yang salah satu nya dengan menggunakan kondom. Sikap Pekerja Seks Komersial terhadap Pencegahan Penyakit menular seksual meliputi sikap profesinya yang beresiko, memiliki sikap bertanggung jawab dengan pernyataan setuju dengan segala sesuatu yang telah dipilihnya dengan segala resiko, kemudian sikap pekerja seks komersial tentang memilih-milih tamu dan pelanggan yang tidak mau menggunakan pengaman memiliki sikap menerima dan merespon dengan pernyataan setuju dengan alasan takut tertular dan tidak setuju dengan alasan tidak enak, untuk sikap PSK tentang melakukan pemeriksaan rutin dan kesehatan diri memiliki sikap menerima dan bertanggung jawab dengan pernyataan setuju untuk periksa rutin, kemudian untuk sikap menyikapi jika harus melayani lebih dari 1 tamu memiliki sikap menerima dan merespon dengan pernyataan setuju jika harus melayani lebih dari satu tamu, dan yang terakhir yaitu sikap PSK terhadap pasangan yang menderita dan sikap untuk melayani pelanggan yang menginginkan seks tidak biasa memiliki sikap tanggung jawab dengan pernyataan tidak setuju karena bisa 
tertular dan menyebabkan PMS. Aktifitas Pekerja Seks Komersial terhadap pencegahan penyakit menular seksual tentang aktifitas terhadap pencegahan penyakit menular seksual, terhadap kebersihan diri sehari-hari sebagian sudah melakukan dengan baik dan beberapa diantaranya ada pada tingkatan persepsi dan respon terpimpin dalam melakukan aktifitas sehari-hari.

Berdasarkan kesimpulan di atas, maka penulis akan memberikan saran Pengetahuan Pekerja Seks Komersial dalam perilaku pencegahan Penyakit Menular Seksual khususnya tentang jenis-jenis dan tanda gejala lebih ditingkatkan lagi, dengan lebih banyak mencari tahu di internet atau bisa bertanya dengan petugas kesehatan, sehingga dapat menjadi dasar untuk mencegah penyakit-penyakit tersebut, juga dapat mengetahui lebih banyak tentang penyakit menular seksual, sehingga bisa ditangani lebih dini. Sikap Pekerja Seks Komersial terhadap pencegahan Penyakit Menular Seksual bagi yang sudah menerapkan, diharapkan tetap menerapkan apa yang telah diketahui tentang pencegahan penyakit menular seksual, tapi bagi yang masih belum menerapkan tentang pencegahan diharapkan lebih berhatihati lagi misal untuk sikap penggunaan kondom dalam melakukan hubungan seksual, ada beberapa yang sudah sadar diri dengan menggunakan pengaman ada yang tidak menggunakan pengaman dalam melakukan hubungan seksual, diharapkan semua sadar dengan bahaya resiko tertularnya penyakit menuar seksual, jadi untuk beberapa sikap yang masih kurang menerapkan pencegahan tentang pencegahan penyakit menular seksual lebih diperhatikan lagi.

\section{DAFTAR RUJUKAN}

Dinkes, (2009). Profil Kesehatan Provinsi Jawa Tengah, dalam http://www.dinkes.com
Kumalasari, Intan, APP \& Andhyantoro, Iwan, S.K.M, (2012). Kesehatan Reproduksi Untuk Mahasiswa Kebidanan dan Keperawatan. Jakarta : Salemba Medika.

Manuaba, Ida Bagus Gde, (2009). Memahami Kesehatan Reproduksi Wanita., Edisi 2. Jakarta : EGC.

Moleong, L.J, (2009). Metodologi Penelitian Kualitatif Edisi Refisi. Bandung : Remaja Rosdakarya.

Notoatmodjo, S, (2012). Promosi Kesehatan dan perilaku Kesehatan Edisi Revisi. Jakarta : Rineka Cipta

Notoatmodjo, S. (2005). Metodologi Penelitian Kesehatan. Jakarta : Rineka Cipta. 